\title{
Metropol Kent Yönetimi Yaklaşımları ve Uygulama Modelleri
}

Tarkan OKTAY 1

\section{Özet}

Kentli nüfusun hızlı artışı ve nüfusun büyük ölçekli kentlerde yığılması dünyadaki genel trendi oluşturmaktadır. Dünya'da kentli nüfusun \%41'i bir milyonun üzerinde nüfusa sahip metropollerde yaşamaktadır. Metropol kentlere özgü problemler, kentle ilgili çalışmalarda önemli bir alan durumuna gelmiștir. Ekonomik, sosyal ve siyasi değișimler kentlerin yönetim modellerini de etkilemektedir. Araştırma kapsamında Metropoliten Reform Geleneği, Kamu Tercihi Teorisi ve Yeni Bölgecilik yaklaşımlarının metropoliten yönetime bakışları incelenmektedir. Ayrıca, metropol kentlerin yönetimi konusunda dünyanın çeşitli şehirlerinde görülen uygulama modelleri, iki ana tasnif çerçevesinde analiz edilmektedir.

Anahtar Kelimeler: Metropol, Metropoliten Yönetim, Büyükşehir Yönetimi, Metropoliten Reform Geleneği, Kamu Tercihi Teorisi, Yeni Bölgecilik.

\begin{abstract}
Rapid increase in urban population and accumulation of population in big scale cities form the major trend in the globe. 41 percent of world's urban population lives in the metropol cities where population is above one million. The problems of the metropol cities have become a major research field in urban studies. Economic, social and political changes effect the administrative models of the cities. Tradition of metropolitan reform, public choice theory, and new regionalism's treatment of metropolitan city governance are investigated within the scope of this research. Additionally, case studies on the issue of metropol city governance in various global cities will be analyzed within the framework of two main classification.
\end{abstract}

Keywords: Metropol, Metropolitan Governance, Metropolitan Reform Tradition, Public Choice Perspective, New Regionalism.

\footnotetext{
${ }^{1}$ Doç. Dr. İstanbul Medeniyet Üniversitesi, e-mail: tarkan.oktay@medeniyet.edu.tr
} 


\section{GíRis}

Dünya'da kentleşme düzeyinin artması, insanlığı kentlere özgü birçok problem ile karşı karşıya getirmiştir. Kentin özelliklerine göre problemlerin içeriği ve boyutları da değişmektedir. Diğer taraftan farklı ülkelerde olmalarına rağmen problemlerin ve üretilen çözümlerin de benzeștiği gözlemlenmektedir. Kentlerdeki ortak sayllabilecek ihtiyaçların başında vatandaşların sağlıklı, güvenli, ekonomik bakımdan gelişmiş, altyapı yeterliliğine sahip, yönetişim kapasitesi yüksek nitelikte kent ortamına ulaşmalarını sağlayacak bir yönetim organizasyonuna sahip olmaları gelmektedir. Dünya'da hızlı değişen ekonomik, teknolojik, siyasal ve sosyal çevre karşısında kent yönetimlerinin hizmet kalitesini korumak ve daha ileriye taşımak için yeniden organize olmaları, kentsel problemlerle ilgili temel tartışma konularından birini oluşturmaktadır.

Sanayi devrimi ile birlikte önemli gelişme gösteren yerel yönetimler, nüfus yığılmalarının ortaya çıkardığı metropol kentlerde yeni bir evreye girdi. Daha küçük ölçekler için geliştirilmiş yönetim modelleri, kentlerin ölçek büyüklügü karşısında yetersiz kaldı. Yerel yönetimlerin dayandığı demokrasi, eşitlik, yeniden paylaşım, etkinlik, özerklik vb. kavramları temel alan uygulama modellerinin yeniden tanımlanması ihtiyacı ortaya çıktı. Bu süreçte demokrasi ile hizmet etkinliği arasında kurulmaya çalışan denge, metropoliten yönetimlerin tasarımındaki temel tartışma alanı oldu.

Metropol kentlerin yönetimi konusundaki arayışlar, uygulamacılar kadar akademik çevrelerin de önemli tartışma alanlarından biridir. Kentlerin çok yönlü niteliği ekonomi, siyaset, yönetim ve teknik gibi farklı disiplinlerde bulunan araştırmacıların metropoliten yönetim konusundaki tartışmalara katkı yapabilmesine imkan sağlamaktadır. Küreselleşme, ekonomik rekabet, yeni yönetim yaklaşımları ve teknolojik gelişmeler yönetim modellerinin tasarımını da etkiledi ve farklı yaklaşımların geliştirilmesini sağladı. Dünyadaki kentleşme seyrinin büyük kentlerin nüfusu ve sayısının artması yönünde olması, gelecek dönemlerde metropoliten yönetim konusundaki tartışmaların aynı yoğunlukta süreceğini göstermektedir.

Metropol kentlerin yönetimi ile ilgili araştırmalar temel olarak iki eksende yürümektedir. Birincisi, Kuzey Amerika ve Avrupa'da geliştirilen ve uygulama sonuçları 
gözlenen metropoliten yönetim yaklaşımlarıdır. Bunlar, metropoliten alandaki yönetim yapısının tasarımı konusunda farklı kriter ve çözümler sunmaktadır. İkinci eksen, teorik yaklaşımları dışlamadan dünyadaki farklı uygulama zenginliğinden de yararlanarak karşılaştırmalı ve derinlemesine analizler ile metropol kent ve yönetimini anlama ve anlamlandırmayı hedefleyen çalışmalardır.

Metropoliten yönetimle ilgili tartışma ve araştırmalar için bir çerçeve sunarak katkı vermeyi amaçlayan bu araştırma kapsamında, ilk olarak tarihsel gelişme sırası ile Metropoliten Reform Geleneği, Kamu Tercihi Yaklaşımı ve Yeni bölgecilik olarak adlandırılan metropoliten yönetim yaklaşımları temel özellikleri bakımından incelenmektedir. İkinci kısımda farklı ülkelerdeki uygulamalardan yola çıkılarak geliştirilen metropoliten yönetim tasniflerinden tercih edilen ikisi ele alınmaktadır.

\section{Metropol Kent Kavramı}

Dünya'da kentli nüfusun 20. yüzyılda kaydettiği önemli artış trendi, 21. yüzyılın ilk çeyreğinde de devam etmektedir. 2014 verilerine göre dünyada 3.9 milyar kişi kentlerde yaşamaktadır. 1950'lilerde dünyadaki kentli nüfus oranı \%30 seviyesinde iken, günümüzde \%53'e ulaşmıştır. Gelişmiş ülkelerde bu oran \%78'e çımakta, az gelişmiş ülkelerde \%48'e kadar düşmektedir. Kuzey Amerika ve Avrupa'da yüksek seviyelere ulaşan kentli nüfusun artış oranı yavaşlarken, özellikle Asya, Güney Amerika ve Afrika'da hızlı kentleşme varlığını sürdürmektedir (United Nations, 2015, s. 21-23).

Dünya'da kentli nüfus miktarının artmasına paralel olarak gelişen diğer bir durum nüfusun gittikçe büyük kentlerde yığılmasıdır. 1950'de nüfusu 10 milyonu geçen sadece iki kent New York ve Tokyo idi. 2014'de 28'e ulaşan bu sayının 2030'da 41'e çıkması beklenmektedir. 2014 verilerine göre 10 milyonu geçen kentler sırasıyla şu şekildedir; Tokyo, Delhi, Şanghay, Mexico City, Sao Paulo, Mumbai, Osaka, Pekin, New York, Kahire, Dakka, Karaçi, Buenos Aires, Kalküta, İstanbul, Chongqing, Rio de Janeiro, Manila, Lagos, Los Angeles, Moskova, Guangzhou, Guangdong, Kinshasa, Paris, Shenzhen, Londra, Jakarta (United Nations, 2015, s. 86).

Birleşmiş Milletler'in 2014 yllı verilerine göre dünyadaki kentli nüfusun \%11,7'si 10 milyon, \%7,7'si 5-10 milyon ve \%22,3'ü 1-5 milyon nüfusa sahip şehirlerde yaşamaktadır. Bu veriler, kentsel nüfusun \%41,7’sinin, 1 milyonun üstündeki şehirlerde 
yaşadığı anlamına gelmektedir. 2030'da bu oranın \%45.3'ye ulaşacağı tahmin edilmektedir (United Nations, 2015, s. 79).

Dünya'da kentlerde yaşayan nüfusun önemli bir kısmının metropol kentlerde yer aldığı ve bu trendin devam edeceği görülmektedir. Özellikle Kuzey Amerika ve Avrupa dışındaki gelişmekte olan ve kentlileşme süreci devam eden ülkelerde kırsal kesimden kentlere yönelen göç dalgalarının dengeli dağılımının sağlanamadığı ve nüfusun ülkenin birkaç ana kentine yöneldiği bir süreç yaşanmaktadır.

Tablo 1. Dünya'daki Kentli Nüfusun Kent Ölçeklerine Göre Dağılımı (\%)

\begin{tabular}{|l|l|l|l|l|}
\hline Nüfus Dilimi & $\mathbf{1 9 7 0}$ & $\mathbf{1 9 9 0}$ & $\mathbf{2 0 1 4}$ & $\mathbf{2 0 3 0}$ \\
\hline Dünyadaki Kentsel Nüfus & 36,6 & 42,9 & 53,6 & 60,0 \\
\hline 10 milyon ve Üstü & 1,5 & 2,9 & 6,3 & 8,7 \\
\hline 5 milyon - 10 milyon & 2,9 & 3,0 & 4,1 & 5,2 \\
\hline 1 milyon - 5 milyon & 6,6 & 8,6 & 11,4 & 13,4 \\
\hline 500.000 - 1 milyon & 3,5 & 3,8 & 5,0 & 6,0 \\
\hline 300.000 - 500.000 & 2,4 & 3,0 & 3,6 & 3,8 \\
\hline 300.000 'den az & 19,7 & 21,7 & 23,2 & 23,0 \\
\hline Kırsal Nüfus & 63,4 & 57,1 & 46,4 & 40,0 \\
\hline
\end{tabular}

Kaynak: United Nations, Department of Economic and Social Affairs, Population Division: World Urbanization Prospects, 2014 Revision: New York, 2015, s. 78.

“Metro" (ana, asıl) ve "Polis" (kent) sözcüklerinden meydana gelen "Metropolis" kavramı ve benzer anlamdaki "Metropol" ile "Metropoliten" kavramları büyük ölçekli kentleri diğerlerinden ayırt etmek için, sanayi devriminden sonra ortaya çıkan Londra, Paris, Tokyo ve New York gibi büyük ölçekli yerleşim Yerleri için kullanılmaya başlamış ve genel kabul görmüştür (Eke, 1985, s. 42; Keene, 2004, s.459-462). Günümüzde büyük ölçekli yerleşim yerleri "metropol" ya da "metropoliten kent" olarak adlandırılmaktadır. $\mathrm{Bu}$ yerleşimlerin yayılmış olduğu alan "metropoliten alan" ya da bulunduğu ülkedeki idari bölümlerin ölçeği paralelinde "metropoliten bölge" olarak da tanımlanmaktadır.

Metropol kent konusunda ayrıntılı bir tanım vermenin temel zorluğunu Kuzey Amerika ve Avrupa'daki metropoller ile dünyanın diğer yerlerindeki metropol kentler arasındaki yapısal farklar oluşturmaktadır. Örneğin, kentsel altyapının gelișmişliği, lüks tüketim hacminin yüksekliği, büyük ölçekli finans kurumlarının varlığı, iş alanları ile konut alanlarının ayrı kent bölgelerinde olması, tarım dıșı sektörlerin ağırlıklı olması, 
gibi nitelikler dünyanın diğer bölgelerindeki metropollerde farklı özellikler gösterebilmektedir. Metropol kentler hakkında literatürdeki bazı tanımlardan (İsbir, 1986, s. 167; Gündüzöz, 2011, s. 3; France ve diğerleri, 1987, s. 11) da yararlanarak genel özelliklere vurgu yapan bir tanım daha kuşatıcı olabilir. $\mathrm{Bu}$ çerçevede metropoliten kenti; ana çekirdeği oluşturan kent merkezine bağlı olarak gelişmiş, bir ya da daha fazla alt düzeyde merkezin bulunduğu, bu merkezlere bağımlı yerleșimlerden oluşan, birden fazla yerel yönetim birimine sahip, büyük ölçekli yerel hizmetlerin sunulduğu, yerleşim alanları ile bütünleşmiş kırsal alanlarla birlikte geniş yüzölçüme yayılmış, bir milyon üstü ve yoğun nüfusa sahip yerleşim alanı olarak tanımlamak mümkündür.

Birden fazla metropol kentin genişlemek suretiyle birbirleri ile birleşmesi ile oluşan devasa kentsel alan ise "Megapol" olarak adlandırılmaktadır. Megapol alanlarda bir metropol kentten diğer metropol kente geçilirken yerleşim alanları arasında bir kesinti söz konusu değildir. Dünya'da başlıca megapol alanları Kuzey Amerika'daki Northeast Megapolis, Avrupa'daki European Megalopolis, Japonya'daki Taiheiyo Belt, Çin'deki Pearl River Delta ve Yangtze River Delta'tir (Megalopolis, Wikipedia). Türkiye'de İstanbul-Kocaeli hattı megapol olma potansiyeli bulunan bir alan durumundadir.

Bir kentin metropolleşme sürecinde bazı karakteristik özellikler söz konusudur. Nüfusun hızla yükselmesi ve yoğunluğun artması ile ivme kazanan süreçte, kentin ana merkezi gelişmeye başlar. Kent, merkezdeki gelişmeye paralel olarak çevredeki yerleşimlere ve kırsal alanlara doğru genişleme gösterir. $\mathrm{Bu}$ süreçte yeni yerleşim alanları oluştuğu gibi, çevredeki küçük yerleşimler büyüyerek merkeze bağlı yeni alt merkezler oluştururlar. Bu süreçte nüfus, ekonomik sektörler, kentsel altyapı yönetim vb. kentsel unsurlar çevreye doğru desantralizasyon süreci yaşar. Merkez kent çevresinde çevre kentler (banliyo) ortaya çlkar. Kentin çevreye doğru desantralizasyonu, kent merkezindeki yoğunlukları, dolayısıyla yerel hizmetlerdeki yoğunlukları da azaltıcı bir etki yapar (Rao, 2007, s. 4-8).

Metropolleşme sürecini planlı olarak yönetebilen kentler, ortaya çıkacak riskleri minimize ederek daha sağlıklı bir kent dokusu üzerinde gelişirler. Kent yönetiminin gelişmenin gerisinde kalması durumunda ise kent merkezindeki yoğunluklar yeteri kadar çevreye desantralize edilemez. Merkez etrafındaki çevre kentler plansız olarak 
gelişir. Kentin merkez bölgesi ile alt merkezler ve çevrede oluşan yerleşimler arasında sağlıklı entegrasyon ve koordinasyon kurulamaz. Kentsel altyapı çevre yerleşimlerdeki gelişmenin gerisinde kalır. Planlama, konut, ulaşım, eğitim, atık yönetimi, su hizmetleri vb. alanlarda ciddi boyutlardaki problemlerle karşı karşıya bir metropol kent ortaya çlkar.

Metropol kentlerin gelişme süreci nüfus artışı yanında kentin ekonomisi ve organizasyonunu da etkilemektedir. Tarım dışı sektörlerden sanayi, ticaret ve hizmetler alanı gelişir. Mesleki hizmetler, haberleşme, müteahhitlik, mühendislik, hukuk, eğitim, çevre, finans, sağlık, ulaşım, turizm, bilişim vb. hizmet alanları gelişme gösterir ve uluslararası nitelikleri artar. Kentin dünya ekonomik, sosyal ve siyasal sistemi ile entegrasyon düzeyi yükselir. Kentteki şirketlerin ölçeği büyür, havalimanı ve liman gibi tesislerin sayısı ve kapasitesi artar, iş yerleri ile konut alanları ayrışmaya başlar, yerel hizmetlerin ölçeği artarak birden fazla yerel yönetim birimleri ortaya çıkar.

Kentsel işlevlerin gelişimi yanında bu işlevlerin kentteki dağılımında da farklılaşma görülür. Ticaret, sanayi, teknoloji vb. gibi benzer işleve sahip birimlerin kentin aynı bölgesinde toplanması ile "yoğunlaşma", özel veya kamu kesimindeki yönetim ve denetim birimlerinin kentin ana merkezinde toplanması ile "merkezileşme", ticari faaliyetlerin kentin merkezi bölgesinden uzaklaşarak çevre bölgelerde yeni iş bölgeleri oluşturması ile "merkezden uzaklaşma", kentteki işlevlerin yer değiştirmesine paralel olarak yüksek gelir gruplarınca terk edilen konutlara daha düşük gelir grubunun yerleşmesi ile de " istila ve ardıllık" olarak adlandırılan süreçler yaşanabilmektedir (Tuzcuoğlu, 2003, s. 82).

\section{Metropoliten Yönetim Yaklaşımları}

Dünyada nüfusun büyük ölçekli kentlerde toplanması, bu yerleşimlerde siyasi, idari, mekânsal, teknik, sosyal ve ekonomik bakımdan diğer yerleşimlere göre farklı boyuttaki karmaşık problemleri de beraberinde getirmektedir. Bu konudaki genel yaklaşım, büyük ölçekli şehirlerin nitelikleri gereği farklı bir kategoride değerlendirilerek, karşılaşılan çok yönlü problemlerin bu şehirlere özgü yaklaşım ve yapılarla çözülmeye çalışılmasıdır. Bu konuda dünyada birçok yönetim modeli uygulanmaktadır. "Metropoliten Yönetim" kavramı metropol kentlerde uygulanan farklı nitelikte yönetim modellerini içinde toplayan çerçeve bir kavram haline gelmiştir. 
Genelde metropoliten alanın tümünden sorumlu, büyük ölçekli yerel hizmetleri yürüten ve koordine eden bir yönetim yapısını ifade etmektedir.

Metropoliten alanların yönetimi ile ilgili akademik çalışmalarda kavramsal çerçeveyi belirleyen 3 ana yaklaşım bulunmaktadır. Metropoliten Reform Geleneği, Kamu Tercihi Teorisi ve Yeni Bölgecilik olarak nitelendirilen yaklaşımların görüşleri sırası ile aşağıda incelenmektedir.

\subsection{Metropoliten Reform Geleneği (Eski Bölgecilik)}

19. yüzyılın sonu ve 20. yüzyılın başında kentsel alanların düzensiz büyümesine paralel olarak, akademik düzlemde metropoliten alanların nasıl bir organizasyona sahip olması gerektiği konusundaki tartışmalar başlamıștır. Kent ekonomistleri, coğrafyacılar, sosyologlar, kamu yönetimi uzmanları ve siyaset bilimciler metropoliten alanların yönetimi için "en iyi yol nedir?” sorusunun cevabına yoğunlaşmışlardır. Bu tartışmalar daha sonraki yıllarda "Metropoliten Reform Geleneği” ve "Kamu Tercihi Yaklaşımı" adıyla iki ana entelektüel yaklaşımın doğmasına yol açmıştır (Kübler ve diğerleri, 2007, s. 474).

Metropoliten Reform Geleneği, 1930'dan sonra hakim olan Keynesyen ekonominin, müdahaleci sosyal refah devleti anlayışının geçerli olduğu bir dönemde, fordist üretim tarzına uyumlu şekilde, Amerika'da ortaya çıkmıştır. Metropoliten alanlarda büyük ölçekli yönetim yapıları ile planlamada etkinlik ve yerel hizmetlerin sunumunda verimlilik sağlanabileceği anlayışı bu yaklaşımın özünü oluşturmaktadır. Metropoliten Reform Geleneği, günümüzde “eski bölgecilik” olarak da tanımlanmaktadır. Metropoliten Reform Yaklaşımı Amerika'nın metropol alanlarında yaşanan birçok problemin temelinde doğrudan doğruya kentsel alandaki siyasi ve idari parçalanmışlığın olduğunu kabul etmektedir (Özgür, 2008, s. 7). Metropoliten alanda çok sayıda özerk ayrı tüzel kişiliğe sahip yerel yönetim birimlerinin varlığı, yerel hizmetlerin eşit biçimde sunulması, verimlilik ve etkinliğin sağlanmasındaki ana engel olarak görülmektedir (Kübler ve Heinelt, 2005, s. 9). Yerel yönetim birimi sayısının çok ve birimlerin nüfus, mücavir alan, kaynak ve kapasiteleri açısından küçük olduğu metropoliten alanlarda; a) hizmet kalitesinin düşeceği, b) birimler arasında ciddi hizmet farklılıkları oluşacağı, c) hizmetlerden sorumlu otoritenin belirlenemeyeceği, d) ölçek ekonomisinden 
yararlanmanın mümkün olamayacağı (e) nitelikli personel çalıştırma ve uzmanlığın sağlanamayacağı savunulmaktadır (Özgür, 2008, s. 6).

Metropoliten reformcular tezlerini verimlilik kazanımları üzerine kurmuşlardı. Metropoliten alanda parçalanmış bir yapı yerine tek yerel yönetimden meydana gelen model aynı alanda görülen yönetimlerin çakışması problemini ortadan kaldıracaktı. Böylece verimliliğin arttırılması ve maliyetlerin azaltılması hedefleniyordu. Metropoliten alanda ekonomik sınırlar ile siyasi sınırların örtüşmemesinin oluşturduğu problemlerin çözümü de benzer bir modelden geçiyordu. Çok sayıda yerel yönetimin varlığı, kamu yönetiminin hesap verebilirliğini ve denetimi zorlaştırmakta, yönetimlerin birbirleri ile çelişen programlar hazırlamalarına neden olmakta, bölgesel problemler konusunda geniş bir uzlaşma sağlanmasını engellemekte idi (Hamilton ve diğerleri, 2004, s. 153).

Metropoliten reformcularda büyük ölçekli kamu bürokrasisinin planlama ve rasyonelliğine güven üst düzeydeydi. Metropoliten alanda büyük ölçekli yapıların ortaya çıkması için birleştirme ve bütünleştirme savunulmaktadır. Metropoliten alanın ekonomik ve sosyal gelişmesinin bölgesel ölçeği ile idari birimlerin sınırlarının örtüşmesi gerektiği kabul edilir. $\mathrm{Bu}$ amaçla da Metropoliten alanda birleşme, banliyölerin merkez kente katılması ile ya da bir metropoliten yönetim kurulması ile gerçekleştirilmelidir. Metropoliten alanda kurulan iki kademeli bir yönetim yapısı, metropoliten alandaki fonksiyonların tümünü kapsayan geniş yetki ve özerkliğe sahip olmalıdır (Kübler ve Heinelt, s. 9).

Metropoliten Reform Anlayıșı'nın 4 önemli ayağı bulunmaktadır. Bunlar; metropoliten alanda desantralize edilmiş birimleri ve yetkileri "merkezileştirme", parçalı bir yapıya sahip metropoliten alanı "bütünleştirme", kapasitesi düşük amatör düzeyden daha profesyonel ve "uzmanlaşmış bürokrasiye" geçiş, idari alan ile siyasal alan arasında net bir ayrım olmayan, siyasetin daha çok müdahil olduğu kurumsal yapılardan bu iki alanın kesin ayrıldığı daha "özerk idari yapılara” geçiş olarak sayılabilir (Sager, 2005, s. 230-231).

Metropoliten Reform Anlayışı, metropoliten alanda merkezileşme ve büyük ölçekli yönetim yapılarının, küçük idari birimlerin bulunduğu parçalı bir modele göre demokrasi bakımından daha elverişli bir siyasal ortam oluşturduğunu da savunur (Özgür, 2008, s. 7). Vatandaşlar, parçalanmış yönetim yapısına sahip bir metropolde, 
günlük hayatta ilişkide olmalarına rağmen, ikamet ettikleri yönetim birimi dışındaki kentsel alanlar için siyasal olarak pasif durumdadır. Kentsel alanın diğer kesimleri ile ilgili siyasal gündemi yeterince takip edemedikleri gibi, siyasal taleplerini de etkin biçimde siyasal sisteme iletemezler. Buna karşın metropoliten alanın tümünden sorumlu büyük ölçekli yönetim yapıları karşısında vatandaşların kentsel problemlerin bütünü ile ilgilenebilmeleri ve siyasal sisteme katılmaları daha etkili biçimde gerçekleşmektedir. Böylece idarelerin metropoliten alanda yaşayan tüm vatandaşlar karşısındaki hesap verebilirlikleri de sağlanabilmektedir.

\subsection{Kamu Tercihi Teorisi ve Metropoliten Yönetim}

1950’li yıllardan itibaren gelişmeye başlayan Kamu Tercihi Teorisi siyasetin ekonomik açıdan analizini temel almaktadır. Kamu tercihi teorisi, James Buchanan ve Gordon Tullock'un başını çektiği “Virginia Okulu “ ile Antony Downs ve George Stigler'in yer aldığı "Chicago Okulu" sayesinde gelişti. Yaklaşımının temellerini neo-klasik iktisatçıların ileri sürdüğü "Piyasa Başarısızlığı” yaklaşımına karşılık geliştirdikleri "Devletin Başarısızlığı" teorisi oluşturmaktadır. Kamu tercihi teorisyenleri devletin başarısızlığının temel nedeni olarak keynesçi ekonomik anlayışa göre hareket eden akademisyenler, bürokratlar ve siyasetçileri görmektedir. Siyasi süreçte alınan karar ve uygulamaları iktisat biliminin kullandığı araç, yöntem ve varsayımlara dayalı olarak incelemeye çalışan kamu tercihi teorisinin temel ilkeleri; toplumsal tercih yerine birey tercihlerini esas alan "metodolojik bireyselcilik", siyasal süreçteki aktörlerin yararlarını maksimize etme istekleri anlaminda "rasyonalite ve maximand" ile siyasal aktörler arasındaki mal ve hizmet değişimini ifade eden "siyasi mübadele"dir. Siyasi süreçlerin işleyişini piyasa süreçleri ile benzer kabul eden yaklaşıma göre piyasanın serbestliğine paralel olarak siyasi süreçler de serbest olmalıdır (Kızılboğa, 2012, s. 92-97).

Metropoliten yönetimler 1930'lu yıllarda tüm metropoliten alanı kapsayan tek bir birim, tek bir otorite olarak örgütlenirken, 1960'lı yıllara doğru parçalı biçimde birden fazla yönetsel birim veya kademeli yönetsel birimler şeklinde örgütlendirilmeye başladı (Tuzcuoğlu, 2003, s. 136). Bu süreçte kamu tercihi teorisine dayalı metropoliten yönetim anlayışı tekçi ve merkeziyetçi metropoliten reform yaklaşımına tepki ve alternatif olarak gelişme gösterdi. Charles Tiebout'nun 1956 yılında yayımlanan "A Pure Theory of Local Expenditures" (Tiebout, 1956, s. 416-424) adlı kamu hizmetlerinin 
yerelleştirilmesi ve etkinliği üzerine makalesi, Kamu Tercihi Yaklaşımı'nın yerel yönetimlerin örgütlenmesi ile ilgili yaklaşımlarının başlangıcı kabul edilmektedir.

Tiebout'a göre kentsel alanda bulunan çok sayıdaki yerel yönetim kamusal hizmetler bakımından tüketici ve seçmen konumundaki vatandaşlara daha fazla seçenek sunar. Bu tercihler arasında vatandaşlar kamu hizmeti ihtiyacı ile gelir ve gider durumlarını dikkate alarak en fazla memnuniyeti sağlayacağına inandığı yerel idarenin bölgesine yerleșir. Metropoliten alanlarda yerel yönetimlerin birleștirilmesi sonucu oluşturulan yönetim modellerinde vatandaşlara sunulan farklı gelir-maliyete dayanan alternatif kamusal hizmet seçenekleri de azalır (Tiebout, 1956, s. 416-424). Seçmenler kendileri için daha avantajlı yerel yönetim bölgesine doğru ikamet değiştirerek adeta ayakları ile oy kullanmaktadır.

Metropoliten alanlarda çok sayıda özerk yerel yönetimlerin varlığı, kamusal hizmetlerin düzeyi, vergi ve maliyetler bakımından bir çeşitlilik oluşturarak vatandaşların tercih edebilecekleri bir ortam sağlar. Çok sayıdaki yerel yönetim arasında oluşacak rekabet ortamı vatandaşların daha az maliyetle daha iyi düzeyde kamusal hizmet alması yanında, kamusal mal ve hizmetlerin üretilmesindeki verimliliği de arttırmaktadır. Metropoliten alanın tümünü yönetmek amacıyla oluşturulan büyük ölçekli tek birimden oluşan yapılar, vatandaşların kamusal hizmetler konusunda bilgilenmeleri, serbestçe tercih yapabilmeleri ve denetim bakımından elverişli bir ortam oluşturmamaktadır (Ostrom ve diğerleri, 1961, s. 838-839).

Kamu tercihi teorisine göre kollektif davranışların temelinde bireysel tercihler bulunmaktadır. Birey, rasyonel olarak davranmakla birlikte kişisel çıkarını öne çıkarmaktadır. Kamu Tercihi Teorisi demokrasinin bir serbest piyasa olduğunu, kamu refahının bireylerin arzularının toplamından başka bir şey olmadığını savunur. $\mathrm{Bu}$ çerçevede devlet müdahalesi aynı zamanda mutluluğun kişisel arayışına da müdahaledir. Bürokratlar egoisttir ve kendi rasyonel yararlarını maksimize etmek için uğraşırlar (Sager, 2005, s. 232).

Bireylerin, kişisel çıkarları bakımından en az maliyetle tercihlerine uygun, en fazla kamu hizmeti aldıkları yerleşim yerinde yaşama eğilimleri vardır. Ancak, farklı alternatiflerin olduğu bir metropoliten alanda vatandaşların seçme hakkı bulunacaktır. Bu farklılaşma ve çeşitlilik, farklı zevk, tercih ve ihtiyaçları olan, ödeme gücü ve isteği ile hizmet kombinasyonu istekleri farklı olan vatandaşların teorik olarak da olsa 
kendilerine en uygun yerleşim birimini bulabilmelerine daha çok fırsat tanır (Özgür, 2008, s. 6). Bu nedenle metropoliten alanda tekçi yaklaşımlar yerine parçalanmış birden fazla yerel yönetim biriminin varlığı vatandaşlara farklı seçeneklerin sunulması için uygun ortam oluşturacaktır. Yerel yönetimler parçalı bir metropoliten yönetim yapısında farklı alternatifleri sunabilmek ve vatandaşların tercihlerini etkileyebilmek için birbirleri ile rekabet halinde olacaktır. Bu rekabet hizmet çeşitliliğini ve kalitesini de yükseltecektir.

Kamu Tercihi Yaklaşımının metropoliten alan için önerdiği yaklaşımlar 4 ana kavram altında incelenebilir. Birincisi, kamu işlemlerindeki karmaşıklığın azaltılması, şeffaflı̆̆ın arttırılması, vatandaşların bireysel tercihlerinin sistem tarafından daha sağlıklı tespiti ve karşılanması için tekçi metropoliten yönetimde "desantralizasyon" yapılması. İkincisi, vatandaşların daha az vergi ödeyerek en çok hizmeti alma konusunda tercihte bulunabilmeleri için metropoliten alanın yönetim olarak "parçalanması". Böylece vatandaşlar istedikleri belediyeye taşınarak tercihte bulunabileceklerdir. Parçalanma küçük ölçeklere ve yüz yüze ilişkilere imkan verdiğinden tekçi merkezi yapılara göre daha demokratik kabul edilmektedir (Sager, 2005, s. 233).

Üçüncü kavram "kendi kendine idare" dir. Tekçi ve büyük ölçekli yapılarda bürokrasi tarafından filtre edilen vatandaş tercihlerinin, parçalanmış ve küçük ölçekli birimlerde kamu politika ve uygulamalarına daha fazla yansıyacağı savunulmaktadır. Dördüncü olarak "siyasi kontrol" kavramı ile bürokrasinin tüm boyutları ile siyasi kontrol altında olması ifade edilebilir. Halkın temsilcisi konumundaki siyasal temsilcilerin kontrol ettiği bürokrasi, yetkilerin desantralize edildiği ve katılımcı bir yönetim modeli ile vatandaşların beklenti ve taleplerini daha fazla dikkate alacak, sistemin siyasi hesap verebilirliliği ve demokratik meșruiyeti daha yüksek olacaktır (Sager, 2005, s. 232).

Kamu tercihi yaklaşımı metropoliten alan yönetimi konusunda önemli katkılar sağladı. Kentsel seçmenlerin tercihlerini ifade edebildikleri yerel siyasi sistem konusunda rasyonel bir gerekçe oluşturdu. Diğer taraftan, metropoliten alanda parçalı yerel yönetim yapısının kentsel hizmetlerin maliyetlerini düşürdüğüne kanıt üretmek için deneysel çalışmalar yapılmasını sağladı. ABD’de o dönemde görece az sayıda metropol yönetim olduğundan, araştırmalarını bölgesel öneme sahip hususların ele alınması amacıyla parçalanmış ya da bütünleştirilmiş bölgelerin göreceli yeterliliği 
üzerine değil, büyük ve küçük ölçekli kentlerin performansının karşılaştırılmasına odakladılar. Buna rağmen bu araştırmalar ideal bir tip olarak bile kamu tercihi yaklaşımının metropoliten alanların yeniden yapılanması konusunda katkıda bulunmasını sağladı (Frisken ve diğerleri, 2001, s. 471).

\subsection{Yeni Bölgecilik ve Metropoliten Yönetim}

Metropoliten Refom Yaklaşımı ve Kamu Tercihi Yaklaşımının metropoliten alanla ilgili yaklaşımları 1970'li yıllara kadar temel iki akım oldu. 1970'den sonra meydana gelen ekonomik ve siyasi gelişmeler "Yeni Bölgecilik" adıyla metropoliten alanların yönetimi ve organizasyonu ile ilgili yeni bir yaklaşımın gelişmesine yol açtı. 1930'dan sonra hakim olan Keynesyen ekonomi ve II. Dünya Savaşı'ndan sonra uygulanan bölgesel politikalar 1970’lerdeki ekonomik kriz sonrasında değişmeye başladı. Kuzey Amerika ve Avrupa karşısında dünyanın diğer bölgelerinde ve özellikle Doğu Asya'da yeni ekonomik aktörlerin ortaya çıkışı sonucu küresel ekonomik rekabetin artması, gelişmiş ülkelerde sanayinin teknolojiye dayalı, esnek ve Post-Fordist üretim tarzına geçmesi gibi faktörler ulusal kalkınma yaklaşımları yerine "bölge"ye odaklı ekonomik kalkınma ve küresel rekabet yaklaşımlarını geliştirdi. Bölge'nin ekonomik temelli yükselişi, metropoliten yönetimler konusundaki yaklaşımları da etkiledi. 1980'lerde en iyi metropoliten yönetim konusundaki arayışlar yönünü, metropoliten alanın bir bütün olarak ekonomik kalkınmada ve küresel rekabette avantaj sağlayacak biçimde nasıl organize edilmesi gerektiğine çevirdi.

1990’lı yıllara kadar metropoliten yönetimle ilgili bilimsel ve siyasi tartışmalar büyük ölçüde metropoliten reform hareketi ve kamu tercihi teorisi arasında oldu. Ancak, metropoliten alandaki güncel meselelerin tartışılması bakımından bu iki düşünce okulu yetersiz kaldı. Çağdaş metropollerdeki demokrasi ve vatandaşlıkla ilgili soruları tartışmak için çok az yol gösterici oldular (Kübler ve Heinelt, s. 12). Diğer yandan, metropol alanda bütünleştirmeye dayalı girişimler başarılı olmadı. Metropollerde bu yönde gerçekleştirilen birçok reform çabası hayal kırıklığı oluşturdu. Kamu tercihinin özerk yerel otoriteler arasındaki rekabete olan inancı ise çoğu metropolde uygulanan deneysel çalışmalarda ortaya çıkan gerçeklikten uzak kaldı. 1990'lı yıllarda, Avrupa ve Kuzey Amerika'da metropoliten yönetim konusunda ampirik çalışma günümüzde "yeni bölgecilik" olarak bilinen üçüncü bir yaklaşımın ortaya çıkmasına yol açtı (Kübler ve diğerleri, 2007, s. 474). 
Bölgeselleşmenin son safhasının ortaya çıkışı 1990'larda başladı. Siyasi Metropoliten reform dalgası "yeni bölgecilik" adını aldı. Yeni bölgecilik yaklaşımının ortaya çıkıştaki en önemli gerekçesi, ekonomik kalkınma ve giderek küreselleşen ekonomi ortamında ekonomik rekabetin sürdürülebilir niteliğe kavuşturulmasıydı. Ekonomik büyümeyi inceleyen çalışmalar yeni analiz birimi olarak kabul edilen kentsel bölgelere yöneldi. Yeni bölgeciler analizlerini metropoliten alandaki yerel yönetimlerin ekonomik bakımdan birbirine bağlı olmasına yoğunlaştırdı. Ekonomik ilişkiler siyasi sınırlar ile kısıtlı değildi. Özel sektör kuruluşları bölgesel ekonomik rekabetin avantajları ve imkanlar konusunda yerel yönetimlere göre daha fazla ilgili ve yetenekli idi. Bölgesel ölçekte gündeme gelen problemlerin çözümü için yerel yönetimlerin özel sektör kuruluşları ile işbirliği içine girmesi ve bir ilişki ağı oluşturması yeni bölgecilerin temel odaklandığı nokta oldu. Tüm metropollerde uygulanabilecek tekdüze idari ve siyasi kapsayıcı ilke ve modeller peșinde değillerdi (Hamilton ve diğerleri, 2004, s. 154).

Yeni bölgeciler kurumsal konsolidasyon, çok kademeli otoriteler, yönetimler arası gönüllü birlikler, kamu-özel sektör ortaklıkları veya özerk bölgeler arasında rekabete dayalı bölgesel ağlar için tek başına herhangi bir model tercihi ifade etmezler. Bununla birlikte yeni bölgeciliği savunan yazarlar yönetimler arası gönüllü birlikler ve kamu-özel sektör ortaklıkları veya özerk bölgeler arasında rekabete dayalı bölgesel ağlar üzerinde yoğunlaşmışlardır. Yeni bölgeciler, yerleşimler arasındaki serbest rekabetin, bölgesel yayılmanın oluşturduğu dışsallıklar ve eşit olmayan kaynaklar nedeniyle gerçekleşemediği ve rekabet yerine işbirliği için metropoliten yönetişimin temel talep olarak geliştiği kanısındadırlar. Yeni bölgeci düşünce, işbirliklerine dayalı metropoliten yönetişime vurgu yapmakta ve bunun için kamu ve özel sektörden katılımcıları içeren hiyerarşik olmayan süreçler ile metropoliten problemlerin çözümünde liderliğin paylaşılmasını savunmaktadır. Burada, yeni bölgecilik yaklaşımının ortaya çıkması ile devletin yönetimden yönetişime dönüşmesi tartışmaları arasındaki paralellik açık olarak görülmektedir (Kübler ve diğerleri, 2007, s. 476).

Metropoliten alanda yeni bölgeciliği savunan bilim adamlarının 3 temel konuya odaklandığı söylenebilir. Birincisi, metropoliten alanda yerel yönetimler arasında gönüllü yöntemlere dayalı işbirliklerini kurmak. İkincisi, metropoliten alanda parçalanmış yönetim yapılarından kaynaklanan olumsuz dışsallıkların giderilmesi problemi. Üçüncüsü, metropol alanda fakirleşen merkezi kent bölgesinin ekonomik ve 
diğer alanlarda rahatlamasının sağlanması. Böylece, merkezi kent bölgesinin metropol alanda diğer yerleşimlerin ekonomilerine çok daha etkili biçimde katkı sunmasının sağlanması sağladı (Frisken ve diğerleri, 2001, s. 467). Yeni bölgecilik, bir taraftan küresel ekonomik rekabete odaklanırken diğer taraftan yerelde sürdürülebilir kapasite oluşturmak için banliyöler ile merkezi kentsel bölge arasında her bakımdan bir bağımlılık ilişkisi ve gelişmişlik benzerliği kurmaya çalışır. Bunu yaparken parçalı ve yayılmış yerleşimlerin olumsuzluklarını da gidermeyi amaçlamaktadır (Norris, 2015, s. 62).

Yeni Bölgecilik Yaklaşımı, metropoliten alanda güçlü bir yönetim oluşturmak için mutlaka kurumsal olarak birleştirilmiş merkezi yapılara ihtiyaç olmadığını, çeşitli bölgesel düzeydeki kurumlar, özel sektör ve sivil toplum arasındaki ilişkilerin geliştirilmesi ile yönetişim kapasitesinin arttırılmasının da güçlü bir metropoliten yönetimi ortaya çıkaracağını savunur (Kübler ve diğerleri, 2007, s. 475). Metropoliten yönetimler çok aktörlü yeni ağ yapısının odağında yer alarak tüm bu ilişkilerin kurulması, sürdürülmesi ve geliştirilmesi rolüne sahiptir.

Yeni bölgecilik metropoliten alanda "yönetim"den "yönetişim"e geçişi hedefleyen bir yaklaşım oldu. Yönetişimin kamu kurumlarının aracılığı ile değil, metropoliten alandaki çok çeşitli aktörler arasındaki etkileşime dayalı olarak hayata geçebileceğini savunur. $\mathrm{Bu}$ süreçte aktörlerin rollerinin katı kurallara dayanmayan biçimde belirlenmesi, metropoliten üstü düzeylerdeki ulusal veya ulusüstü yapılar tarafından bölgesel işbirliği teşvik mekanizmalarının iyi kurgulanmış olması ve etkili siyasi liderlik önemli başarı unsurları olarak öne çıkmaktadır (Kübler ve Heinelt, s. 10). Bölgenin küresel rekabet karşısında refahını geliştirebilmesi ve sürdürebilmesi için merkez kent ve banliyölerin bir bütün olarak gönüllülüğe dayalı biçimde organize olmaları ve yönetişim temelli ilişki ağları kurmaları yeni bölgeciliğin temel hedefleri arasındadır (Norris, 2015, s. 60-61).

\section{Metropoliten Yönetim Modelleri}

Metropoliten yönetim kavramı, genel olarak metropoliten alanın yönetimi ile ilgili "yapı" ya da "kurumsal düzenlemeler" anlamına gelir. En saf hali ile "metropoliten model" olarak adlandırılabilir (Lefèvre, 1998. s. 10). Metropoliten kentlerin yönetim modelleri konusunda dünyada birbirinden farklı yapılarla karşılaşılmaktadır. 
Ülkelerdeki tarihsel birikim, siyasal yaklaşımlar, ülkenin gelişmişlik düzeyi, hizmet etkinliği, yerel yönetim anlayışı ve uygulamaları, şehir ölçekleri, kentsel altyapının gelişmişlik düzeyi, kentlerin coğrafi özellikleri, metropolün gelişme süreci vb. faktörler metropol alandaki yönetim modeli üzerinde etkili olmaktadır. $\mathrm{Bu}$ parametrelerin niteliğine göre farklı ülkelerde veya $A B D^{\prime}$ de olduğu gibi aynı ülkede dahi farklı metropoliten kent yönetim modelleri ile karşılaşmak mümkündür.

Dünyada metropol kentlerdeki yönetim modellerinin çeșitliliğine paralel olarak bu konuda literatürde farklı tasnifler yapılmaktadır. Bunların bir kısmı konuyu daha genel bir bakış açısı ile ele alarak sınıflandırma yoluna giderken, bazıları daha ayrıntılı analize dayanmaktadır. Bu çalışmada sınıflandırma çabalarından ikisi ele alınacaktır. İlki metropoliten yönetimleri 4 ana grupta toplayarak daha basit ama etkili ve kapsayıcı bir kategorik çerçeve çizmektedir. Buna göre metropoliten yönetim modelleri, tek kademeli, iki kademeli, isteğe bağlı (gönüllü) ve özel amaçlı kuruluşlar olmak üzere dört ana gruba ayrılmaktadır (France ve diğerleri, 1987, s. 16-27; Bird ve diğerleri, 2008, s. 195-213, Tuzcuoğlu, 2003, s.138-223; Slack, 2007, s. 14-24.).

Tek kademeli model, metropoliten alanda tek bir yerel yönetim kademesinin bulunmasını ifade eder. Genellikle metropol alandaki parçalanmış yapıyı oluşturan çok sayıdaki belediyenin merkezdeki büyük belediye yapısına katılması ya da belediyelerin kaynaşarak tek ve büyük yeni bir belediye yapısı oluşturması biçiminde görülmektedir. Katılma ve kaynaşma sürecinde ilgili belediyeler yetkilerini ve özerkliklerini yitirerek daha büyük bir yapının parçası haline gelmektedir. Bununla birlikte birleșen belediyelerin kimlikleri tüzel kişiliğe sahip olmayan yeni bir hizmet bölgesi veya hizmet şubesi olarak devam etmektedir. Tek kademeli modelin diğer farklı bir biçimini ise, çok sayıda belediyeden oluşan parçalanmış yapının, üstünde ikinci bir kademe olmadan, metropol alandaki yerel hizmetleri tek kademe olarak üstlenmesi oluşturmaktadır. Toronto, Melbourne, Canberra başlıca örnekleri oluşturmaktadır.

İki kademeli modelde, metropoliten alandaki yerel hizmetlerden sorumlu alt ve üst olmak üzere tüzel kişiliğe sahip iki ayrı kademeden oluşan bir yönetim yapısı bulunmaktadır. Üst kademe metropol alan ölçeğinde örgütlenirken alt kademe, ilçe ve belde gibi metropol alanın bir parçasını ifade eden daha küçük ölçekli belediyelerden oluşmaktadır. Üst kademedeki yönetimin yürütme ve karar organları doğrudan halktan 
seçilebileceği gibi dolaylı olarak alt kademedeki belediyeler tarafından da oluşturulabilmektedir.

Yerel hizmetlere ilişkin yetki ve görevler iki kademe arasında paylaştırılır. Üst kademe ölçek ekonomisinin sağladığı avantajları kullanmaya yönelik ve metropoliten alanın bütününe faydası yayılan hizmetlerden sorumludur. Alt kademe ise metropoliten alanın bir parçasını oluşturan kendi ölçeğindeki yerel nitelikteki hizmetlerden sorumlu tutulmaktadır.

Üst kademe ile alt kademe arasındaki yetki ve kaynak paylaşımında ülkeden ülkeye farklılıklar gözlemlenebilmektedir. Alt kademenin çok zayıf örgütlendiği, yetki ve sorumlulukların büyük ölçüde üst kademeye ait olduğu New York örneğine karşın, Londra'da alt kademe, üst kademeye göre çok daha fazla yetki ve sorumluluğa sahiptir. Türkiye'de de geçerli olan iki kademeli modelde, üst kademe daha fazla yetki ve sorumluluğa sahip olmakla birlikte, alt kademeye de önemli düzeyde sorumluluk verilmiş ve daha dengeli bir yapı kurulmuştur. Londra, New York, Tokyo, İstanbul, Paris ve Barcelona iki kademeli yönetim modeline sahip dünyadaki başlıca şehirler olarak belirtilebilir.

İsteğe Bağlı (gönüllü) yönetim modeli, metropoliten alanda tek kademe biçiminde örgütlenmiş çok sayıdaki belediyenin yerel hizmetlerle ilgili yardımlaşma amacıyla oluşturdukları çeşitli birliktelik modellerini ifade eder. Mevcut belediye modelinin minimal düzeyde yeniden yapılanması sonucu ortaya çıkan bu yapı, kendisini oluşturan belediyelerin katılması konusunda yasal ya da diğer zorlayıcı bir etki olmaksızın isteğe bağlı bir ilişki biçimine sahiptir.

Gönüllü yapıları oluşturmak ya da belli bir süre sonra ortadan kaldırmanın nispeten kolaylığı, belediyeler arası ilişkilerde alternatif bir çözüm sunmaktadır. Belediye birlikleri ve hizmet sözleşmelerine dayalı işbirlikleri biçiminde görülen bu model, bazı belediyelerin koordinasyonu ve hizmetlerde verimlilik bakımından yararlı olabilmekle birlikte, metropoliten alanın tümünü kapsayan koordinasyon noktasında yetersiz kalabilmektedir. Bu tür modelin önemli örneklerini Bologna, Los Angeles ve Vancouver'daki bazı uygulamalarda görmek mümkündür.

Özel amaçlı kuruluşlar, metropoliten alan ölçeğinde temiz su, atık su, katı atık, rekreasyon alanları, elektrik ve doğalgaz gibi belirli bir hizmetin yürütülmesine yönelik olarak kurulurlar. Ayrı bir tüzel kişiliğe ve ayrı bir bütçeye sahip olan bu kuruluşlar 
metropoliten alandaki yerel yönetim yapısı tarafından denetlenmektedir. Hizmetin sunulmasına yönelik teknik organizasyon yönü ağır basan bu kuruluşların genellikle, halkın katılımına imkan tanıyan mekanizmaları yetersiz ve hesap verebilirlikleri de düşük düzeydedir. Özel amaçlı kuruluşlar tarafından yürütülen hizmetlerdeki siyasi sorumluluğu, bu kuruluşları denetleyen yerel yönetimler üstlenir. Siyasi etkilerden nispeten uzak oluşları, bu kurumların hizmete yönelik profesyonelliğe dayalı karar alabilmelerine de imkan sağlar. Metropoliten alanda birden fazla özel amaçlı örgütün faaliyetlerini koordine etmek, modele göre değişmekle birlikte, yerel yönetimler için güçlüklere sahiptir. Türkiye'deki büyükşehirlerde kurulan su ve kanalizasyon idareleri bu modelin tipik örnekleridir.

Dünya'daki metropoliten alanların yönetimi ile ilgili yukarıda ayrıntılarına değinilen genel tasnif yanında, 2012 yılında OECD bünyesinde Shah tarafından yapılan çalışmada daha ayrıntılı bir sınıflandırma yapılmıştır. Metropoliten alandaki yönetim kademesi sayısı, kademeler arası veya aynı kademe içindeki koordinasyon ilişkileri sinıflandırmada temel kriter olarak kabul edilmektedir. Metropoliten yönetimlerin 6 sınıfa ayrıldığı tasnif şu şekildedir (Shah, 2013, s. 13-19):

a) Üniter Metropoliten Yönetim: Metropoliten alandaki çok sayıda belediyenin tek bir yapıda birleştirilmesi, tek bir şehir yönetim yapısının bulunması ya da tek kademeli bir yönetim yapısının varlığını ifade eder. Bu yönetimin örnekleri olarak Prag, Yogyakarta, Addis Ababa, Bern, Melbourne, Canberra, Toronto sayllabilir.

b) Dikey Koordinasyona Dayalı Metropoliten Yönetim: Bu türde genelde eyalet ya da il yönetimi ile metropol kent yönetimi bir arada bulunur. Ayrıca, metropoliten alanın tümünde ya da büyük kısmında örgütlenmiş bir üst kademe ve alanın küçük bölümlerinde örgütlenmiş ayrı tüzel kişiliğe sahip alt kademe yerel yönetimler söz konusudur. İki kademeden oluşan yönetim yapısında koordinasyon, denetim ve büyük ölçekli hizmetlerin sorumluluğu üst kademededir. Üst kademe ile alt kademe arasında hizmetler ve organlar arası ilişkilerde dikey bir koordinasyon sağlanmıştır. Üst kademe organlarında dikey koordinasyon kapsamında alt kademeden temsilciler görev yapar. Başlıca örneklerini Pekin, Tokyo, Madrid, Tiran, Varşova, Zagreb, Bangkok, Berlin, Seul, Montreal, Şangay oluşturur. Türkiye'deki büyükșehir belediye sistemi bu kategoriye girmektedir. 
c) Yatay Koordinasyona Dayalı Zorunlu Íki Kademeli Metropoliten Yönetim: Metropoliten alanda kanuni zorunluluğa dayanan ve iki kademeden oluşan bir yönetim yapısı bulunmakla birlikte, her kademenin birbirinden bağımsız sorumluluk alanları açık şekilde tanımlanmıştır. Genellikle iki kademenin de meclisleri doğrudan halk tarafından seçilir. Üst kademe, yerel hizmetlerde alt kademedeki belediyeler arası koordinasyonu sağlar. Ancak, üst kademe ile alt kademe organları arasında dikey bir koordinasyon kurulmamıştır. Bu tür yönetime Belgrad, Üsküp ve Kopenhag şehirlerindeki yönetim modeli örnek olarak gösterilebilir.

d) Yatay Koordinasyona Dayalı Gönüllü İki Kademeli Metropoliten Yönetim: Metropoliten alandaki belediyelerin bazı hizmetleri gönüllü biçimde aralarında kurdukları ortaklık anlaşmaları ya da hizmet sözleşmelerine dayalı olarak yürütmelerini ifade eder. Helsinki, Vancouver ve birçok ABD metropolünde görülmektedir.

e) Koordinasyona Dayalı Olmayan İki Kademeli Metropoliten Yönetim: Metropoliten alanda bölgesel ve yerel yönetimler bir arada bulunmakla birlikte, aralarındaki dikey ya da yatay koordinasyonun düşük düzeyde olduğu modeli ifade eder. Kişinev ve Bükreş bu modele örnektir.

f) Koordinasyona Dayalı Olmayan Bölünmüş Metropoliten Yönetim: Bu modelde metropoliten alanda özerkliğe sahip çok sayıda yerel yönetim, bazen farklı eyalet ya da il yönetimi altında ancak, aralarında düşük koordinasyona dayalı olarak hizmet yürütürler. Bu parçalı yapıyı koordine eden üst bir yapı bulunmamaktadır. Başlıca örnekleri Delhi, Haydarabad, Jakarta, Kalküta, Mumbai, Cape Town, Milan ve Washington DC'de görmek mümkündür.

Metropoliten yönetimle ilgili gerek teorik yaklaşımlar ve gerekse uygulama modellerinin çeşitliliği "En iyi model nedir?" sorusunun cevabını vermeyi zorlaştırmaktadır. Metropoliten yönetim modellerini "iyi bir model" olup olmadığ bakımından değerlendirmek için bazı araștırmacılar tarafından kriter setleri de geliștirilmiştir. Bunların ilki; yerel taleplere duyarlılık, erişilebilirlik ve hesap verebilirlik, hakkaniyet, dışsallıklar ve ölçek ekonomisidir (Slack, 2007,s. 9-13). İkincisi; denetim, etkinlik, siyasi temsil ve kendi geleceğini belirleme hakkıdır (Ostrom ve diğerleri, 1961, s. 835-837). Üçüncüsü ise siyasi meşruiyet, yerel özerklik, geniş yetki sahibi olma ve kapladığı alanın uygunluğudur (Lefèvre, 1998. s. 10). Bu kriterleri ne ölçüde karşıladıklarına göre metropoliten yönetimlerin nitelikleri de 
değerlendirilmektedir. Örnek olarak ele alınan üç kriter setinden de yararlanarak, metropoliten yönetim modellerini analiz etmek amacıyla yeni bir kriter seti de önerilebilir. Bu kriterler; yetki ve görev alanının mevzuat ve mekan düzleminde yeterli genişliğe sahip olması, kurumsal yapı ve hizmet organizasyonunda ölçek ekonomisinin temel alınması, geniş yerel özerkliğe sahip olması, meşruiyeti yüksek bir siyasi temsil sistemi ve yönetişim kapasitesinin yüksekliği olarak kurgulanabilir.

\section{Sonuç ve Değerlendirme}

Günümüzde kentler ekonomik, sosyal, siyasi, teknolojik ve kültürel çok yönlü değişim ve gelişim ile karşı karşıyadır. Bir taraftan yeni kentler yükselirken diğer taraftan var olan kentlerin düzeylerini koruma ve geliştirme çabaları söz konusudur. Kuzey Amerika ve Avrupa ülkelerinde nüfusun gerek kentler arasında ve gerekse kentsel alanlarda desantralize edilmesi bu bölgelerde nüfusun dengesiz ve yoğun biçimde yığıldığı alanları sınırlamıştır. Buna karşın sanayileşmenin ve beraberinde kentleşmenin daha geç dönemlerde başladığı ve göç dalgalarının ülke genelinde dengeli biçimde dağıtılamadı̆̆ı, ülkelerde birkaç büyük şehrin nüfus yığılması sonucunda devasa ölçekli kentler haline geldiği bir tablo söz konusudur.

21. yüzyılın ortalarına doğru kentlerde yaşayan nüfusun yarıya yakınının 1 milyonun üzerindeki metropol niteliğine sahip kentlerde yaşayacağı analizlerden anlaşılmaktadır. Gelecek dönemlerde kentsel problemlerle ilgili tartışmaların odak noktalarından birini, günümüzden çok daha fazla biçimde, metropol kentler oluşturacaktır. Metropol kentler, sahip olduğu büyük ölçek ve yoğun nüfus nedeniyle yerel yönetimler alanında geliştirilen model, hizmet organizasyonu, siyasal katılım mekanizması ve hizmet standartları gibi konuları önemli ölçüde farklılaştırmıştır. Bu konularda gerek akademik düzeyde ve gerekse uygulamacıların yeni model ve çözüm arayışları sürekliliğini korumaktadır.

Avrupa ve Kuzey Amerika'da metropol kentlerle ilgili yönetim yaklaşımları ve uygulamalar bu bölgelerin tarihsel seyri ile paralellik göstermektedir. Ekonomik, siyasal ve toplumsal gelişmelere paralel biçimde metropoliten yönetimle ilgili tasarımların da farklılaştırıldığı ve geliştirildiği bir süreç söz konusudur. Metropoliten Reform Yaklaşımı, metropoliten ölçekte konsolidasyonu savunurken, geliştirildiği dönemdeki ekonomik 
yaklaşıma uyumluluk yanında yerel hizmet açıklarının oluşturduğu problemleri çözme amacını da taşıyordu. Kamu Tercihi Teorisinin tam tersi yaklaşımı, önceki yaklaşımın aksayan yönlerini geliştirme amacı yanında, dönemin farklı ekonomik, toplumsal ve siyasal yaklaşımlarının bakış açısını yansıtmaktaydı. Benzer şekilde, yeni bölgecilik yaklaşımı da küresel düzlemdeki ve kentlerdeki çok boyutlu değişim ve trendleri dikkate almaktadır. Bunu yaparken, Avrupa ve Kuzey Amerika'daki metropollerin zaten iyi durumda olan yerel hizmetlerin düzeyi ile ilgilenmenin ötesine geçerek, metropoliten yönetimi küresel bağlam içinde yönetişim, sürdürülebilir kalkınma ve ekonomik rekabet boyutları olan farklı bir düzeye taşımaktadır. Yönetim yapılarında ise eski bölgeciliğin hiyerarşiye dayalı modelleri yerine ağ temelli modelleri esas almaktadır.

Metropolitan kentlerin yönetimi konusunda dünyada yeknesak bir model bulunmamaktadır. Modellerin çeşitliliği, kentin çok boyutluluğu ve dinamikliği yanında, ülkelerin siyasi ve idari anlayışlarının da bir ürünüdür. Dünyadaki metropoliten yönetimle ilgili teorik yaklaşımlar ve uygulama modellerinin karşılaştırmalı analizleri, mevcut modellerin anlaşılması ve anlamlandırılması yanında, yeni modelleri geliştirilmesi bakımından da yararlı bir çaba durumundadır. En iyi metropoliten yönetimin kurulmasında anahtar kavram ise "maksimum" değil "denge"dir. Ülkedeki yerel yönetim anlayışı, yerel hizmetlerin gelişmişlik düzeyi, nüfus hareketleri, yerel siyasetin niteliği ve coğrafi özellikler gibi metropoliten alanın kendine özgü faktörlerini dikkate alan, demokratik kriterler bakımından kabul edilebilir düzeylerde dengeyi sürdürülebilir biçimde sağlayacak bir model inşası "en iyi" arayışında öne çıkmaktadır. Bu durum, aynı zamanda her ülkede farklı metropoliten yönetim modellerinin varlığını sürdürmeye devam edeceği anlamına da gelmektedir.

Asya, Güzey Amerika ve Afrika'daki metropollerin gelişim süreci ve gelişmişlik düzeyi Avrupa ve Kuzey Amerika'dakilerden farklılık göstermektedir. Bu bölgelerdeki metropol kentlerin yönetim modelleri konusunda Kuzey Amerika ve Avrupa tecrübesi geldiği nihai nokta olarak değil, en baştan itibaren bir bütün olarak yararlanılacak bir örnek durumundadır. Çünkü birçok metropol karma gelişmişlik düzeylerine sahiptir. Sanayi öncesinden teknolojik devrime kadar olan tüm dönemler karma biçimde aynı metropol bütününde görülebilmektedir. Kentsel altyapı, ekonomik organizasyon, insan kaynakları kapasitesi, yerel hizmet düzeyi, eğitim, sağlık, gelir düzeyi gibi toplumsal parametrelerdeki farklılıklar ve siyasal sistem özellikleri her ülkenin metropol kentleri 
ile ilgili kendi özel yönetim modelini geliştirmesini zorunlu kılmaktadır. Bu ülkeler için Kuzey Amerika ve Avrupa tecrübesinin bütünü yanında benzer özelliklere sahip diğer ülkelerdeki örnekler de yeni model ve uygulama geliştirme süreçlerinde yararlanılacak kaynak durumundadır.

Metropol kentlerin küresel rekabetin önemli bir unsuru haline gelmesi, bu kentlerin yönetimlerini kentsel hizmetlerin sunumu ölçeğinden çıkararak uluslararası ekonomik rekabetin birer aktörü haline getirmiştir. Küresel olan ile yerel olan arasındaki ilişkinin iç içe geçtiği günümüzde, metropoliten yönetimlerin uluslararası bir aktör olarak küresel-yerel dengesini kurması önem kazanmıştır. Yerel halkın ihtiyaç, talep ve ortak yararı ile rekabet ortamının gerekleri ve talepleri dengenin kurulacağ başka bir noktayı oluşturmaktadır. Yönetimler bakımından dengeye giden yol, yerel düzeyde demokrasi ve hizmetlerdeki etkinlik dengesini muhafaza ederek demokrasi ve küresel rekabet arasında yeni bir denge noktası daha inşa edilmesinden geçmektedir. $\mathrm{Bu}$ aynı zamanda kamu yönetiminin mekânsal örgütlenmesinin geleceğini belirleyecek unsurlardan biri durumundadır.

\section{Kaynakça:}

- Bird, R. ve Slack, E., Fiscal Aspects of Metropolitan Governance", Eduardo Rojas, Juan R. Cuadrado Roura ve José Miguel Fernández Güell (ed.), Governing the Metropolis: Principles and Cases, Inter-American Development Bank, David Rockefeller Center for Latin American Studies, 2008, s. 193-259.

- Eke, A. E., "Anakent Yönetimi ve Yönetimlerarası İlişkiler: Batı Deneyimi ve Türkiye", Amme İdare Dergisi, 1985, C. 18, S. 4, s. 41-62.

- France, G., Feldman, L. D., Horgan, D., Ünlü, H. ve Yıldırım, S., Metropolitan Yönetim Dünya'da ve Türkiye'de, İstanbul: Marmara ve Boğazları Belediyeler Birliği Yayını, 1987.

- Frisken, F. ve Norris, D. F., "Ragionalism Reconsidered”, Journal of Urban Affairs, Vol. 23, Issue 5, 2001, s. 467-478. 
- Gündüzöz, İlker, Türkiye Uygulamaları Çerçevesinde Metropol Belediye Kavramı: Avantajlar ve Dezavantajlar, Ankara: Türkiye Belediyeler Birliği Yayını, 2011.

- Hamilton, D. K., Miller, D. Y. ve Paytas, J., "Exploring The Horizontal And Vertical Dimensions Of The Governing of Metropolitan Regions", Urban Affairs Review, Vol. 40, No. 2, 2004, s. 147-182.

- İsbir, E. G., Şehirleşme ve Meseleleri, Ankara: Ocak Yayınları, 1986

- Keene, D., "Metropolitan Comparisons: London as a City-State”, Historical Research, 76, 2004, s. 459-480.

- Kızılboğa, R., "Kamu Tercihi ve Anayasal İktisat Teorilerinin Değerlendirilmesi”, NEÜ Sosyal Bilimler Enstitüsü Dergisi, 2, 2012, s. 91-109.

- Kübler, D. ve Heinelt, H., "Metropolitan Governance Capacity, Democracy and the Dynamics of Place", Metropolitan Governance: Capacity, Democracy and the Dynamics of Place, Hubert Heinelt ve Daniel Kübler (ed.), Routledge, New York, 2005, s. 8-28.

- Kübler, D. ve Schwab, B., "New Regionalism in Five Swiss Metropolitan Areas: An Assessment of Inclusiveness, Deliberation and Democratic Accountability", European Journal of Political Research, 46, 2007, s. 473-502.

- Lefèvre, C., "Metropolitan Government and Governance in Western Countries: A Critical Review", International Journal of Urban and Regional Research, Vol. 22, Issue 1, 1988, s. 9-25.

- $\quad$ Norris, D. F., Metropolitan Governance in America, London: Routledge, 2015.

- Ostrom, V., Tiebout, C. M. ve Warren, R., "The Organization of Government in Metropolitan Areas: A Theoretical Inquiry, The American Political Science Review, 55(4), 1961, s. 831-842.

- Özgür, H., "Metropoliten Alanların Yönetimine Kamu Tercihi ve Klasik Yönetim (Metropoliten Reform) Yaklaşımlarının Bakışları", Yerel Siyaset Dergisi. S. 26, 2008, s. 5-10.

- Rao, N., Cities in Transition: Growth, Change and Governance in Six Metropolitan Areas, London: Routledge, 2007.

- Sager, F., "Metropolitan Institutions and Policy Coordination: The Integration of Land Use and Transport Policies in Swiss Urban Areas", Governance: An International Journal of Policy, Administration and Institutions, Vol. 18, No. 2, 2005, s. 227-256.

- Shah, A., "Grant Financing of Metropolitan Areas: A Review of Principles and Worldwide Practices", Policy Research Working Paper 6002, The World Bank, 2012. 
- Slack, E., "Managing the Coordination of Service Delivery in Metropolitan Cities: The Role of Metropolitan Governance”, Policy Research Working Paper 4317, The World Bank, 2007.

- Tiebout, C. M. (1956), "Pure Theory of Local Expenditures, The Journal of Political Economy, Vol. 64, No. 5, s. 416-424.

- Tuzcuoğlu, F., Metropoliten Yönetim, Sakarya Kitabevi, 2003.

- United Nations, Department of Economic and Social Affairs, Population Division: World Urbanization Prospects, 2014 Revision: New York, 2015, http://esa.un.org/unpd/wup/Publications/Files/WUP2014-Report.pdf, (04.01.2016). 